\title{
GLACIAL EROSION OF A HIGH ARCTIC VALLEY
}

\author{
By JOHN ENGLAND
}

(Department of Geography, University of Alberta, Edmonton, Alberta T6G 2H4, Canada)

\begin{abstract}
A large valley, ideally suited for "selective linear erosion" by ice, extends from the Kreiger Mountains to Tanquary Fiord, north-central Ellesmere Island. During the last glaciation, the outlet glacier at the head of the valley advanced $18 \mathrm{~km}$ and was at least $250 \mathrm{~m}$ thick where it contacted the sea in the lower valley. Erosion of bedrock inside the last ice limit is recorded by an abraded diabase dike, and by crag-and-tail features developed in limestone. During deglaciation (7800 B.P.), melt-water streams along the ice margin incised a large alluvial fan that pre-dates the last glaciation. The fan shows little alteration by the overriding ice and its final erosion by the melt-water streams incised, but did not remove, its original ice-wedge polygons.

The preservation of the fan indicates that the glacier was locally non-erosive and that it probably advanced across the fan by over-riding a protective frontal ice apron. Although it is commonly assumed that such alluvial fans occupying glaciated valleys are of post-glacial age, this need not be the case in permafrost terrain. In fact, at this site, there has been a net increment of alluvium versus glacial erosion or deposition spanning the last glacial cycle. The paper discusses the processes of erosion associated with sub-polar glaciers and questions whether erosion by them or more pervasive ice is responsible for such High Arctic valleys and fiords.
\end{abstract}

RÉsumÉ. Erosion glaciaire d'une vallée du Haut Arctique. Une grande vallée, idéalment disposée pour une "érosion linéaire sélective" par la glace, s'étend depuis les monts Kreiger jusqu'au Fjord Tanquary, au centre nord de l'île Ellesmère. Au cours de la dernière glaciation, le glacier qui en sortait avançait de $18 \mathrm{~km}$ et son épaisseur dépassait $250 \mathrm{~m}$ au contact de la mer. L'érosion du lit rocheux en deçà de la dernière extension glaciaire est gravée dans un dyke érodé, et dans le calcaire qui montre des fissures et des moulures. Au cours de la déglaciation (7800 B.P.), les ruisseaux d'eau de fonte le long des bords du glacier ont incisé de grands cônes alluviaux antérieurs à la dernière glaciation. Ces cones alluviaux ne montrent que peu d'altération par la glace qui s'écoulait dessus, et l'érosion finale par les courants d'eau de fonte découpa, sans les emporter, les polygones originaux à coins de glace.

La conservation des cónes de déjection indique que le glacier, localement n'a pas érodé, et qu'il s'est

\section{INTRODUCTION}

The efficacy of erosion by High Arctic glaciers remains poorly understood. Little erosion is predicted by a theoretical, maximum ice cover over the Queen Elizabeth Islands, Arctic Canada (Fig. 1), because much of the ice was cold-based (Sugden, 1978). Nevertheless, the channelling of ice streams down pre-glacial fluvial valleys presumably caused "selective linear erosion" (Sugden, 1978) that overdeepened these valleys, producing fiords (cf. Peltier, 1966; Blake, 1970). At present, neither the occurrence nor the effects of such a maximum ice cover are documented for the Queen Elizabeth Islands, although erratics and melt-water channels at high elevations have been reported for many areas (Sim, 1961; Hattersley-Smith, 1969; England, vraisemblablement avancé sur les cônes en chevauchant un culot de glace protecteur. Bien qu'on suppose habituellement que de tels cônes de déjection occupant les vallées glaciaires soient postérieurs à l'époque glaciaire cela ne semble pas être le cas sur le permafrost. En fait à cet endroit, il y a eu alluvionement plutôt qu'erosion ou dépót glaciaire pendant la dernière glaciation. Cet article discute les processus d'érosion associés aux glaciers subpolaires et pose la question de savoir si leur érosion ou celle d'une masse de glace plus importante est responsable de telles vallées ou fjords du Haut Arctique.

Zusammenfassung. Glaziale Erosion eines Tales in der Hohen Arktis. Ein grosses Tal, hervorragend geeignet für "selektive lineare Erosion" durch das Eis, erstreckt sich von den Kreiger-Bergen zum Tanquary-Fjord im Norden des mittleren Ellesmere Island. Während der letzten Vereisung rückte der Auslass-Gletscher am Kopf des Tales um $18 \mathrm{~km}$ vor und war an der Berührungsstelle mit dem Meer im unteren Tal mindestens $250 \mathrm{~m}$ dick. Die Erosion des Felsbettes innerhalb der letzten Eisgrenzen lässt sich an der Abrasion eines Diabas-Dammes und an Schürferscheinungen im Kalkstein ablesen. Wăhrend des Eisrückzuges (7800 vor der Gegenwart) schnitten sich Schmelzwasserströme längs des Eisrandes in einen grossen alluvialen Schuttfăcher ein, der vor der letzten Vereisung entstanden war. Der Fächer zeigt wenig Veränderung durch das darüberströmende Eis; bei seiner letztlichen Erosion durch die Schmelzwasserströme wurden zwar seine ursprünglichen Polygone aus Eiskeilen angeschnitten, aber nicht abgetragen.

Die Erhaltung des Fåchers zeigt, dass der Gletscher lokal keine Erosion ausübte und dass er vermutlich beim Vorrücken über den Fächer ein frontales Schutzschild aus Eis zu überströmen hatte. Obwohl allgemein angenommen wird, dass solche alluvialen Făcher, die in vereisten Tälern liegen, postglazialen Alters sind, muss dies im PermafrostGelände nicht der Fall sein. Tatsächlich weist diese Stelle einen Nettozuwachs alluvialen Materials gegenüber glazialer Erosion oder Ablagerung auf, der den letzten Vereisungszyklus überspannt. Der Beitrag diskutiert die mit subpolaren Gletschern verbundenen Erosionsprozesse und stellt die Frage, ob Gletschererosion oder mehr die Durchdringung mit Eis für die Entwicklung solcher Täler und Fjorde in der Hohen Arktis verantwortlich ist.

1976, 1978; Blake, 1977; England and others, 1981; Hodgson, 1985). On the other hand, during the last glaciation of northern Ellesmere Island, most glaciers advanced only $20-40 \mathrm{~km}$ beyond their present margins due to the constraints imposed by extreme aridity and the calving of glaciers within fiords (England, 1983, in press; Bednarski, in press). Therefore, the extent to which glaciers are responsible for the major valleys and fiords of the Queen Elizabeth Islands is unknown (England, 1985).

\section{FIELD WORK}

During the summer of 1984, I investigated the Quaternary deposits of a glaciated valley that extends from the ice-covered Kreiger Mountains to the mouth of 


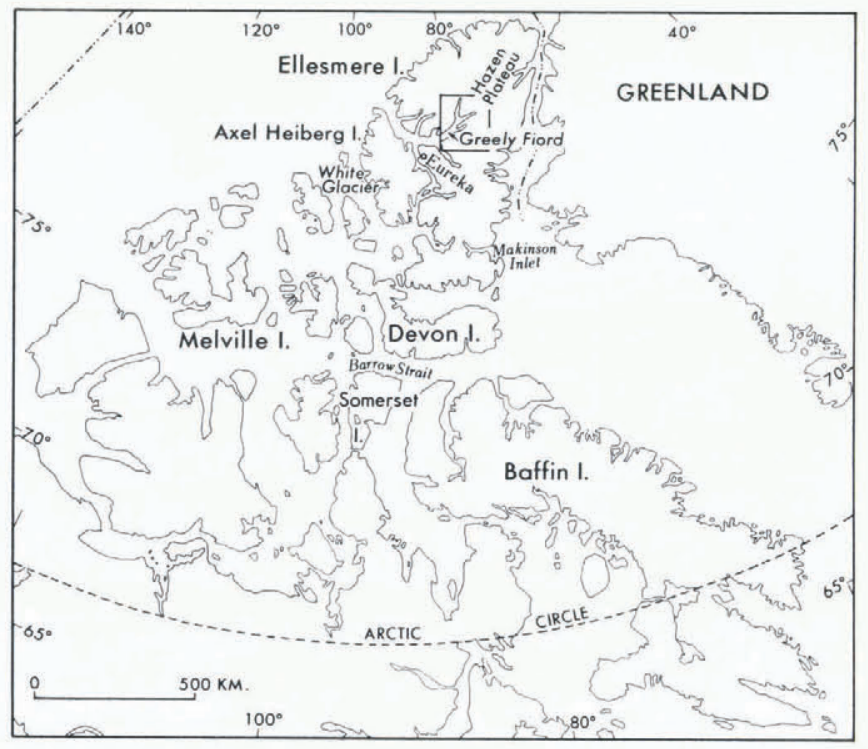

Fig. 1. Location map of the Queen Elizabeth Islands. The field area shown in Figure 2 is outlined by the rectangle.

Tanquary Fiord, north-central Ellesmere Island (Fig. 2). The valley is $18 \mathrm{~km}$ long, $2-3 \mathrm{~km}$ wide, and up to $1100 \mathrm{~m}$ in relief. Today, the head of the valley is occupied by a large outlet glacier that advanced to Tanquary Fiord during the last glaciation. At that time, lateral moraines were deposited in the lower part of the valley ( $8 \mathrm{~km}$ from sea-level) at $300 \mathrm{~m}$ a.s.l. marking a local ice thickness of at least $250 \mathrm{~m}$.
In this vicinity, up to $6 \mathrm{~m}$ of till are exposed along the present river, blanketing the bedrock. The till, in turn, is overlain by marine silts which contain in-situ shells at $76 \mathrm{~m}$ a.s.1. dated $7805 \pm 125$ B.P. (S-2649).

Localized glacial erosion is manifested, c. $3 \mathrm{~km}$ from the coastline where a diabase dike has been plucked, grooved, and striated by a southerly ice flow toward Flora Island, Tanquary Fiord (Figs 2 and 3). This flow diverges somewhat from the axis of the valley (north-west to south-east), because the ice which deposited the moraines

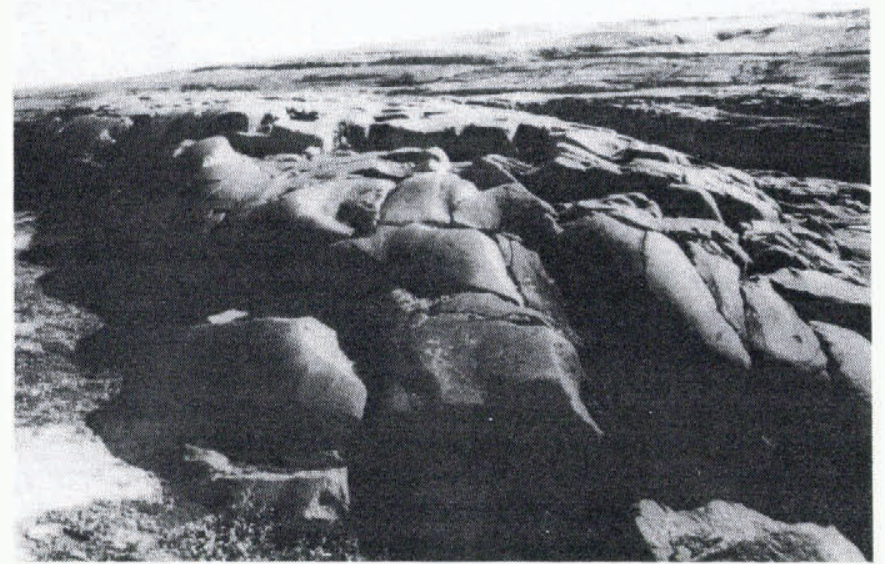

Fig. 3. Plucked, grooved and striated diabase dike in the lower valley. Former direction of ice flow was north-south. Bedrock outcrop covers an area of c. $400 \mathrm{~m}^{2}$. The view is taken in down-ice direction.

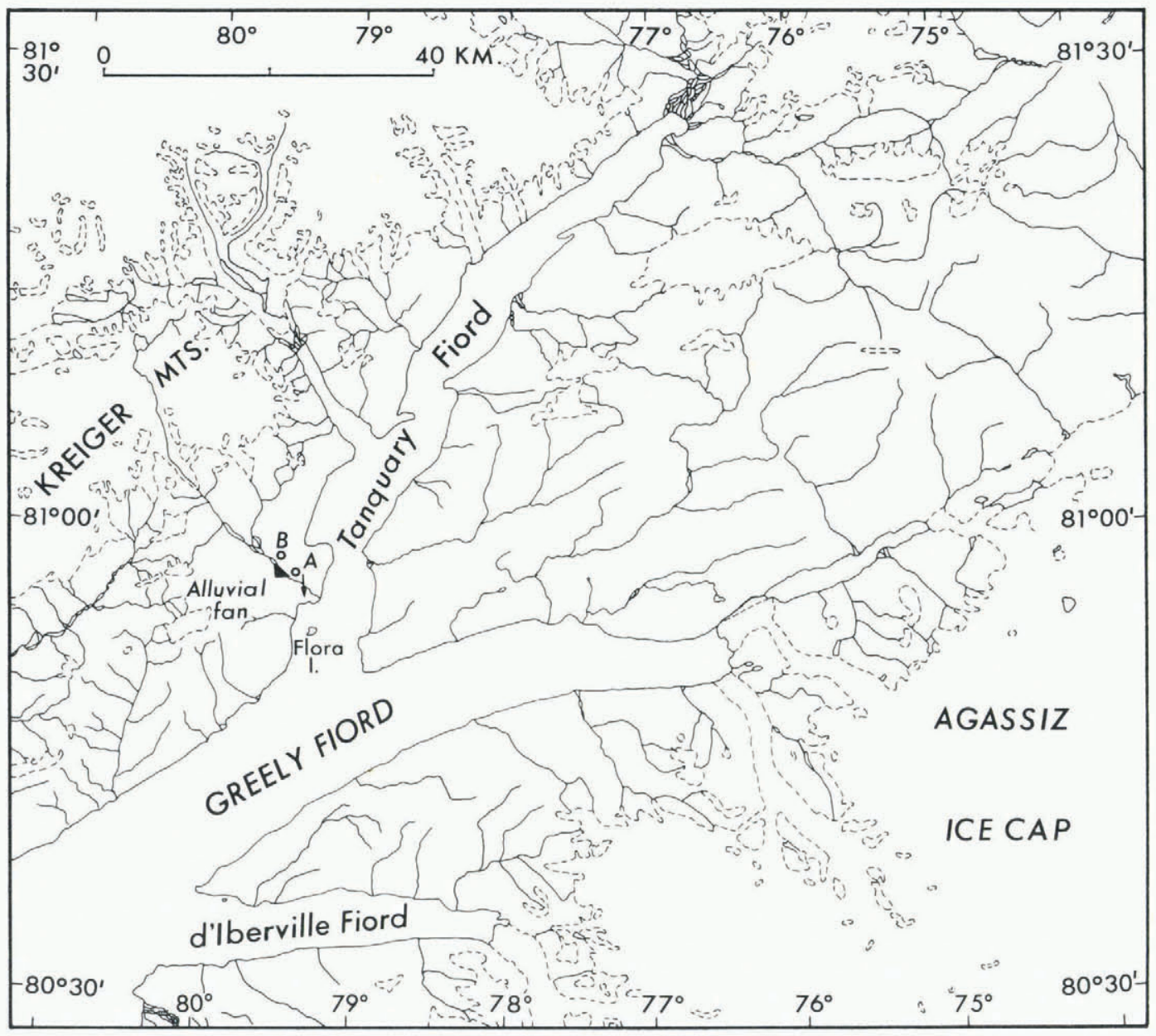

Fig. 2. Field area of the glaciated valley extending from the Krieger Mountains to Tanquary Fiord. Glacially abraded bedrock in the lower valley shows former north-south flow (arrow) immediaely down-valley from the glaciated alluvial fan. The fan was cut by melt-water channels (dashed lines) when ice retreated from site $A$ to site $B$. 
was being deflected by a large gypsum hill along the lower east side of the valley while spreading out into Tanquary Fiord. Immediately up-valley from the abraded diabase dike are abundant crag-and-tail features comprised of low ridges of limestone extending from the lee sides of more resistant chert nodules (Fig. 4). The crag-and-tail is aligned with the sculptured diabase dike and therefore they were eroded

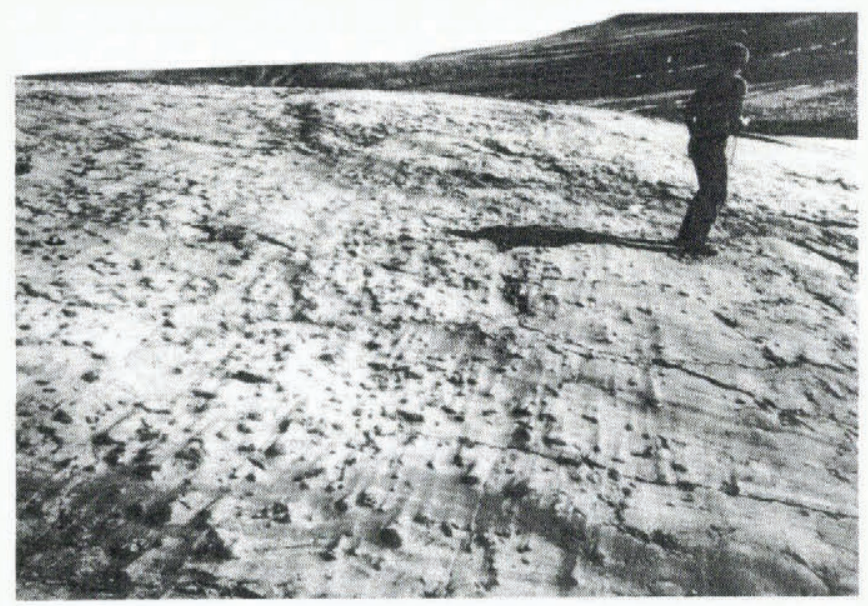

Fig. 4. Small crag-and-tail composed of limestone ridges on the lee sides of more resistant chert nodules. The ridges are commonly $<5 \mathrm{~cm}$ high and often $>25 \mathrm{~cm}$ long.

along a similar flow line. The limestone ridges are commonly $<5 \mathrm{~cm}$ high and from 10 to $>100 \mathrm{~cm}$ long.

During deglaciation of the lower valley (7800 B.P.), ice-contact deltas were deposited into the sea, marking the local marine limit at $116 \mathrm{~m}$ a.s.1. (site A, Fig. 2). By the time the ice front reached site B (Fig. 2), $2 \mathrm{~km}$ farther up-valley, relative sea-level had fallen from 116 to $108 \mathrm{~m}$ a.s.1., indicating that $8 \mathrm{~m}$ of restrained rebound (Andrews, 1970) occurred beneath the retreating ice across this distance. This amount of emergence $(8 \mathrm{~m})$ could have been accomplished in 200-300 years of ice retreat given a rate of initial emergence of $\sim 3 \mathrm{~m} / 100$ year (England, 1983). Therefore, the average rate of retreat between sites $A$ and B (Fig. 2) was c. $10 \mathrm{~m}$ year $^{-1}$.

Between sites $\mathrm{A}$ and $\mathrm{B}$, two former melt-water streams have incised a large alluvial fan, producing two sloping escarpments c. $75 \mathrm{~cm}$ high and $>100 \mathrm{~m}$ long. These former channels are nested in the lower valley at the base of the fan and their gradients represent successive positions of the retreating ice margin (Fig. 5a). Because these escarpments were cut during deglaciation, the alluvial fan must pre-date the last glaciation. The degree of alteration of the fan caused by the over-riding ice is minimal and the final glaciofluvial incision along the ice margin is estimated to be similar to the present depth of the active layer in this area $(\sim 75 \mathrm{~cm})$. Moreover, tundra polygons on the original surface of the fan cross the escarpments indicating that the melt water incised, but did not remove, their underlying ice wedges (Fig. 5b). Conversely, since deglaciation, these escarpments have not been muted or buried by subsequent mass wastage (solifluction) or alluviation.

\section{DISCUSSION}

Abraded bedrock and the subsequent deposition of up to $6 \mathrm{~m}$ of till indicate that some erosion of the valley occurred during the last glaciation. Although such abraded bedrock cannot be dated directly, it is assumed to be the product of the last glaciation because: (1) it occurs inside the last ice limit; (2) the lateral moraines marking this limit are bordered down-valley by a gypsum hill that would align the flow of ice with the observed striations and crag-and-tail features; and (3) the abrasion is freshly inscribed and laterally capped by till, in turn, overlain by deglacial marine silts dated c. 7800 B.P. The extent of the abraded bedrock indicates that during the last glaciation the
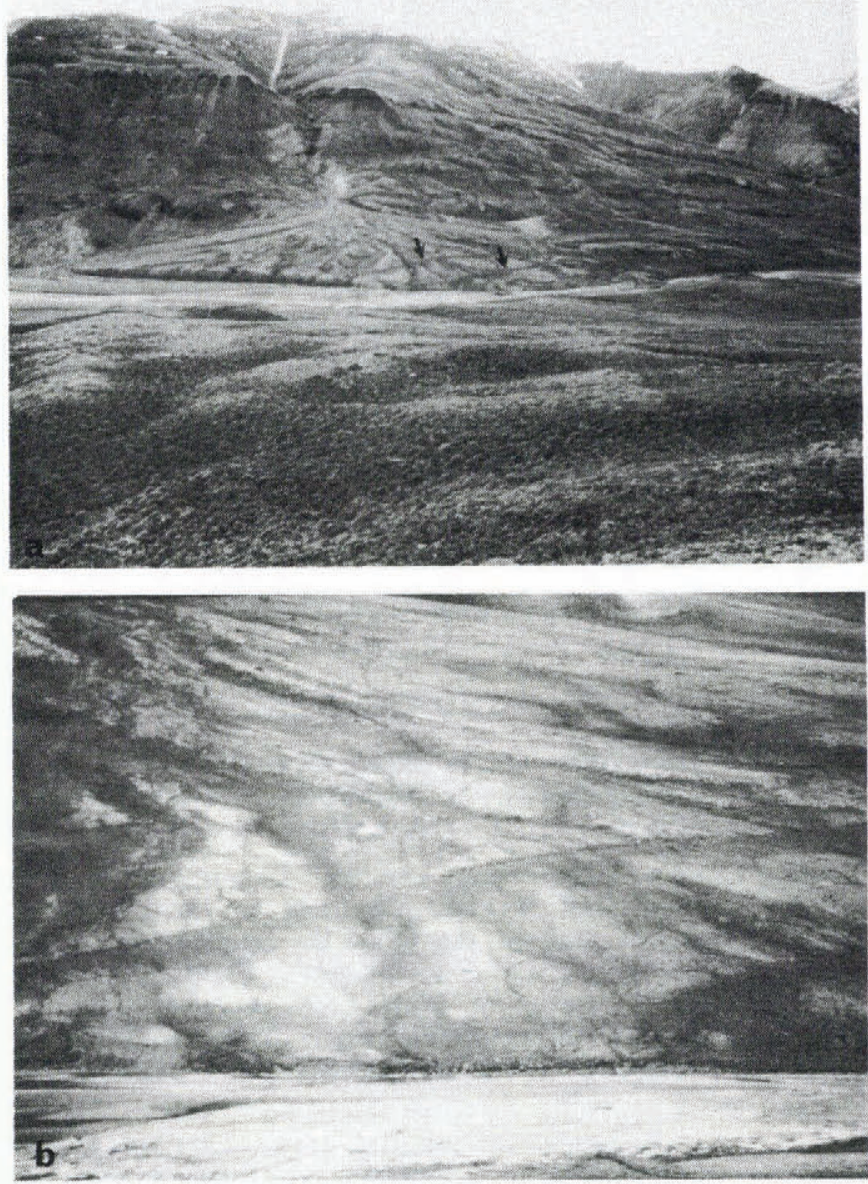

Fig. 5. (a) View from the ice-contact, marine limit (site A) westward to the glaciated alluvial fan (centre background). The two linear incisions from the melt-water channels occur on the lower right side of the fan.

(b) Telephoto view of the same two escarpments cut by lateral melt-water streams across the pre-existing alluvial fan. The escarpments are estimated to represent incision similar to the depth of the modern active layer $(\sim 75 \mathrm{~cm})$. The upper (oldest) escarpment is $c .100 \mathrm{~m}$ long and it has not been altered by subsequent mass movement or alluviation. Note that the original ice-wedge polygons extend across the upper escarpment.

ice remained grounded at least to within $3 \mathrm{~km}$ of the present coastline (Fig. 2). Although the areas of abraded bedrock within the valley are generally small $\left(<2500 \mathrm{~m}^{2}\right)$, they nonetheless represent a minimum estimate for such abrasion because much of the bedrock is buried beneath till, colluvium, or marine sediments. However, compared to the abraded bedrock, a larger area of the valley $\left(1 \mathrm{~km}^{2}\right)$ is occupied by an alluvial fan that pre-dates the last glaciation. Although the fan occurs immediately up-stream from the abraded bedrock, it has been little altered by the over-riding ice. It is apparent, therefore, that in this valley, different erosional regimes have characterized the glacier bed and, as is the case today, such sub-polar glaciers probably varied from cold-based to warm-based conditions on a local scale (Müller, 1976; Hambrey and Müller, 1978).

Today, in the Canadian High Arctic, the most effective erosional processes associated with sub-polar glaciers include: (1) pro-glacial thrusting of permafrost blocks commonly composed of glaciofluvial or glaciomarine sediments that are subsequently over-ridden and entrained by the advancing ice (cf. Kălin, 1971; Klassen, 1982; Stewart and England, 1983); and (2) pro-glacial melt water that incises both unconsolidated sediment and bedrock, producing channels nested in the direction of ice retreat (cf. Blake, 1981; Dyke, 1983). Little is known about subglacial abrasion, although it is recognized that cold-based ice can erode bedrock providing it has sufficient basal debris (cf. Sugden, 1978). 
Boulton (1979) has also observed frozen eolian sands that were deformed and plucked beneath over-riding cold-based ice in Wright Valley, Antarctica. Nevertheless, moraines and till blankets ( $>1 \mathrm{~m}$ thick) are rare over large areas of the Canadian High Arctic, suggesting that erosion and re-deposition by these glaciers was slight.

Modern sub-polar glaciers that are advancing of ten do so by over-riding ice-rich debris aprons that accumulate by dry calving along oversteepened ice fronts (Shaw, 1977). Consequently, new basal ice is passively incorporated such that little active erosion can occur at the glacier bed. This is illustrated eloquently on east-central Ellesmere Island, where a retreating glacier is exposing dead, intact plant communities previously over-run by ice at least 400 years ago (Bergsma and others, 1984). In the same area, the retreat of a glacier, following the most recent Neoglacial advance, has exposed an alluvial fan covered by "coarse bouldery ablation till" (Blake, 1981, fig. 10, p. 211). Finally, on north-central Baffin Island, Falconer (1966) also reported preserved vegetation dated c. 330 B.P. that was exposed by the retreat of thin ice caps during the first half of the present century.

The observations presented here indicate that, although a glacier at least $250 \mathrm{~m}$ thick advanced down a valley ideally located for selective erosion, this did not remove or significantly alter a large alluvial fan that lay in its path. The fan occurs adjacent to abraded bedrock that covers less area of the valley. It is apparent that the glacier advanced passively over the fan, presumably by over-riding a frontal ice apron that covered the undeformed (non-thrusted) fan. Subsequently, the strength provided by permafrost within the over-ridden fan exceeded the forces of entrainment or deformation exerted by the ice. If the fan had not been incised by lateral melt-water streams during deglaciation, one would normally assume that the fan was of post-glacial age. However, because the fan pre-dates the last glaciation, it is apparent that there has been a net increment of alluvium versus glacial erosion or deposition at this site. Similar observations have been made on Somerset Island, central Arctic Canada, where colluvial slopes with solifluction features and patterned ground cover thousands of square kilometers. Although these landforms have been reactivated during the post-glacial, they are developed nonetheless on old colluvium and residual terrain that pre-date at least the late Wisconsinan glaciation (personal communicatioin from A.S. Dyke, 1985). Therefore, in permafrost terrain, one must reject the assumption that all sediments mantling deglaciated valleys are of post-glacial age.

The question that follows is whether the erosive capacity of High Arctic glaciers is responsible for the profiles of such valleys, let alone the much larger fiords commonly occupied by water depths of $300-900 \mathrm{~m}$ (Hattersley-Smith, 1969). The concept of selective linear erosion has been widely used to explain similar valleys. Most notably, zones of selective linear erosion by warm-based ice have been predicted for the Laurentide ice sheet at its maximum (including Arctic Canada), based on a pervasive ice cover with a theoretical profile and basal thermal regime (Sugden, 1977, 1978). On a more local scale, Blake (1978, p. 176) invoked selective linear erosion to explain the topography of the Makinson Inlet area, south-east Ellesmere Island, stating that ... "This type of landscape is characterized by valleys in which tremendous amounts of scouring take place along pre-existing drainage lines of structural lineaments ...". In the case of the valley discussed in this paper, the proponents of selective linear erosion could argue that its profile was cut during an earlier glaciation when pervasive ice presumably over-rode both the valley and its adjacent interfluves. Subsequently, during less extensive glaciations, it also could be argued that selective linear erosion did not occur beneath isolated outlet glaciers because they would have been thinner, and thereby mainly cold-based and protective. If so, it could be concluded that the evidence presented in this paper does not conflict with the concept that selective linear erosion produced the valley's profile.

So far, there is no such evidence for an earlier, pervasive ice cover causing the scale of erosion presently attributed to selective linear erosion in the Canadian High
Arctic. To the contrary, above and beyond the limit of the last glaciation in this valley, there is widespread weathered bedrock without till sheets and certainly with few erratics. Farther out in Greely Fiord (into which the valley in question leads) there is also little evidence of glaciation other than the expansion of local ice caps. Therefore, evidence for massive glacial erosion and re-deposition, as would be required if the size of these valleys and fiords was caused by such a pervasive glaciation, is lacking. It is unacceptable to assume that all the moraines and till sheets re-deposited from such erosion are below present sea-level, and that this pervasive ice also crossed interfluves without depositing similar material! Indeed, in the central part of the Canadian Arctic Archipelago, well-preserved river valleys, likely of Tertiary age, are preserved on the floor of Barrow Strait, arguing against significant glacial erosion of that channel (Bornhold and others, 1976; Dyke, 1983).

Finally, although the valley glacier discussed in this paper was much smaller than the regional ice sheet invoked for selective linear erosion, this does not mean that the erosional effects of the smaller glacier are not diagnostic of the effects of earlier glaciations. For example, other Arctic valley glaciers of similar size and thickness (e.g. White Glacier, Axel Heiberg Island) may locally reach pressure melting-point and therefore contribute to basal erosion (Müller, 1976; Hambrey and Müller, 1978). Furthermore, it is inconsistent to dismiss the erosive power of this valley glacier due to its smaller size, because it has been shown that effective abrasion does not require excessively thick ice (Boulton, 1974). Therefore, because this glacier (250 m thick) did little to alter this valley's profile during the last glaciation, it is considered just as valid to assume that earlier glaciations did no more!

In conclusion, selective linear erosion persists in the literature as a fundamental concept used to explain the development of glacial landscapes. Despite the widespread acceptance of selective linear erosion, one must not lose sight of the fact that in Arctic Canada it is based solely on a theoretical model which assumes a pervasive ice cover whose very presence and dynamics remain to be demonstrated. Moreover, it has not been demonstrated that this concept takes precedence over alternative causes for such valleys; for example, faulting (Bird, 1967; England, 1985). Therefore, further consideration of the erosive capacity of glaciers is warranted, particularly as it pertains to the evolution of the fiords and inter-island channels of Arctic Canada which have been explained routinely by glacial overdeepening. This, in turn, has created a circular view of high-latitude ice sheets that may not be valid.

\section{ACKNOWLEDGEMENTS}

The field work was logistically supported by the Polar Continental Shelf Project, Energy, Mines and Resources, Ottawa. Additional financial support for the research was provided by the Natural Science and Engineering Research Council of Canada (NSERC grant A6680). Thanks are expressed to $\mathbf{K}$. Lindstrom, University of Alberta, who assisted me in the field. G. Lester, Head of the Cartographic Division, Department of Geography, University of Alberta, and R. Pakan, of the same Division, provided the maps and photographs, respectively. S. Fowler and F. Metcalfe typed the manuscript. Finally, A.S. Dyke, Terrain Sciences, Geological Survey of Canada, brought to my attention similar observations he had made on the Somerset Islands. Two anonymous reviewers also provided helpful comments that led the author to refine his objections to selective linear erosion.

\section{REFERENCES}

Andrews, J.T. 1970. A geomorphological study of post-glacial uplift with particular reference to Arctic Canada. London, Institute of British Geographers. (Special Publication No. 2.)

Bednarski, J. In press. Late Quaternary glacial and sea level events, Clements Markham Inlet, northern Ellesmere Island, Arctic Canada. Canadian Journal of Earth Sciences. 
Bergsma, B.M., and others. 1984. Entombed plant communities released by a retreating glacier at central Ellesmere Island, Canada, by B.M. Bergsma, J. Svoboda, and B. Freedman. Arctic, Vol. 37, No. 1, p. 49-52.

Bird, J.B. 1967. The physiography of Arctic Canada with special reference to the area south of Parry Channel. Baltimore, John Hopkins Press.

Blake, W., jr. 1970. Studies of glacial history in Arctic Canada. 1. Pumice, radiocarbon dates, and differential postglacial uplift in the eastern Queen Elizabeth Islands. Canadian Journal of Earth Sciences, Vol. 7, No. 2, Pt. 2, p. 634-64.

Blake, W., jr. 1977. Glacial sculpture along the east-central coast of Ellesmere Island, Arctic Archipelago. Geological Survey of Canada. Paper 77-1C, p. 107-15.

Blake, W., jr. 1978. Aspects of glacial history, southeastern Ellesmere Island, District of Franklin. Geological Survey of Canada. Paper 78-1A, p. 175-82.

Blake, W., jr. 1981. Neoglacial fluctuations of glaciers, southeastern Ellesmere Island, Canadian Arctic Archipelago. Geografiska Annaler, Vol. 63A, Nos. 3-4, p. 201-18.

Bornhold, B.D., and others. 1976. Submerged drainage patterns in Barrow Strait, Canadian Arctic, by B.D. Bornhold, N.M. Finlayson, and D. Monahan. Canadian Journal of Earth Sciences, Vol. 13, No. 2, p. 305-11.

Boulton, G.S. 1974. Processes and patterns of glacial erosion. (In Coates, D.R., ed. Glacial geomorphology. Binghamton, NY, State University of New York, p. 41-87. (Publications in Geomorphology.))

Boulton, G.S. 1979. Processes of glacier erosion on different substrata. Journal of Glaciology, Vol. 23, No. 89, p. 15-38.

Dyke, A.S. 1983. Quaternary geology of Somerset Island, District of Franklin. Geological Survey of Canada. Memoir 404.

England, J. 1976. Late Quaternary glaciation of the eastern Queen Elizabeth Islands, N.W.T., Canada: alternative models. Quaternary Research, Vol. 6, No. 2, p. 185-202.

England, J. 1978. The glacial geology of northeastern Ellesmere Island, N.W.T., Canada. Canadian Journal of Earth Sciences, Vol. 15, No. 4, p. 603-17.

England, J. 1983. Isostatic adjustments in a full glacial sea. Canadian Journal of Earth Sciences, Vol. 20, No.6, p. 895-917.

England, J. 1985. On the origin of high Arctic fiords. (In Abstracts of the 14th Arctic Workshop. Arctic land-sea interaction. 6-8 November, 1985. Dartmouth, Nova Scotia, Bedford Institute of Oceanography, p. 51-53.)

England, J. In press. A paleoglaciation level for north-central Ellesmere Island, NWT. Arctic and Alpine Research.
England, J., and others. 1981. Multiple glaciations and marine transgressions, western Kennedy Channel, Northwest Territories, Canada, by J. England, R.S. Bradley, and R. Stuckenrath. Boreas, Vol. 10, No. 1, p. 71-89.

Falconer, G. 1966. Preservation of vegetation and patterned ground under a thin ice body in northern Baffin Island, N.W.T. Geographical Bulletin, Vol. 8, No. 2, p. 194-200.

Hambrey, M.J., and Müller, F. 1978. Structures and ice deformation in the White Glacier, Axel Heiberg Island, Northwest Territories, Canada Journal of Glaciology, Vol. 20 , No. 82 , p. $41-66$.

Hattersley-Smith, G. 1969 . Glacial features of Tanquary Fiord and adjoining areas of northern Ellesmere Island, N.W.T. Journal of Glaciology, Vol. 8, No. 52, p. 23-50.

Hodgson, D.A. 1985. The last glaciation of west-central Ellesmere Island, Arctic Archipelago, Canada. Canadian Journal of Earth Sciences, Vol. 22, No. 3, p. 347-68.

Kälin, M. 1971. The active push moraine of the Thompson Glacier, Axel Heiberg Island, Canadian Arctic Archipelago. McGill University, Montreal. Axel Heiberg Island Research reports, Glaciology, No. 4.

Klassen, R.A. 1982. Glaciotectonic thrust plates, Bylot Island, District of Franklin. Geological Survey of Canada. Paper 82-1A, p. 369-73.

Müller, F. 1976. On the thermal regime of a high-Arctic valley glacier. Journal of Glaciology, Vol. 16, No. 74, p. 119-33.

Peltier, B.R. 1966. Development of submarine physiography in the Canadian Arctic and its relation to crustal movements. (In Garland, G.D., ed. Continental drift. Toronto, University of Toronto Press, p. 77-101. (Royal Society of Canada. Special Publication No. 9.))

Shaw, J. 1977. Till body morphology and structure related to glacier flow. Boreas, Vol. 6, No. 2, p. 189-201.

Sim, V.W. 1961. A note on high-level marine shells on Fosheim Peninsula, Ellesmere Island, N.W.T. Geographical Bulletin, No. 16, p. 120-23.

Stewart, T.G., and England, J. 1983. Holocene sea-ice variations and paleoenvironmental change, northernmost Ellesmere Island, N.W.T., Canada. Arctic and Alpine Research, Vol. 15, No. 1, p. 1-17.

Sugden, D.E. 1977. Reconstruction of the morphology, dynamics, and thermal characteristics of the Laurentide ice sheet at its maximum. Arctic and Alpine Research, Vol. 9, No. 1, p. 21-47.

Sugden, D.E. 1978. Glacial erosion by the Laurentide ice sheet. Journal of Glaciology, Vol. 20, No. 83, p. 367-91. 